\title{
AMMI CANADA 2014 ANNUAL CONFERENCE: ABSTRACT TITLES
}

\section{Abstracts to be delivered at the 2014 Annual Conference of the Association of Medical Microbiology and Infectious Disease Canada, April 3 to 5, Victoria, British Columbia, alphabetized according to the surname of the first author. Full-text abstracts can be accessed at www.pulsus.com}

\begin{abstract}
Al Hashami H, Allen U, Schechter T, Yau Y. Clinical significance and correlation between EBV qualitative PCR on plasma and whole blood EBV viral load in haematopoietic stem cell transplant (HSCT) pediatric patients Alhetheel A, Somily A, Alzamil F, Albarrag A, Iqbal SM, Alsaadi MM. Detection of circulating respiratory viruses in Riyadh using a multiplex real-time PCR
\end{abstract}

Allen U, Hu P, Pereira S, Paton T, Beyene J, Khodai-Booran N, Dipchand A, Hébert D, Ng V, Nalpathamkalam T, Read S. Genetic diversity of Epstein-Barr virus in the setting of transplant relative to nontransplant settings: Proof-of-principle

Almohri H, Smith S, James D, Morris C. Evaluation of the value of testing ciprofloxacin susceptibility in Salmonella sp by concurrent nalidixic acid disk diffusion and ciprofloxacin disk diffusion using the new revised CLSI disk diffusion breakpoints

Almohri H, Smith S, van Zuilen L. Evaluation of three chromogenic media for the detection of vancomycin-resistant enterococci (VRE)

Antonishyn NA, Birch D, Agopsowicz C, Schmalenberg K, McDonald RR, Levett PN, Horsman GB. Adoption of massively parallel real-time PCR assays for detection of viral and bacterial pathogens on a nanofluidic biochip Balakumar S. The National Notifiable Diseases Database (NDDB): A new resource for Public Health

Barrett L, Daigh L, Wang C, Johl J, Kottilil S. HCV clearance is associated with improved immune phenotype

Baxter M, Adam HJ, McCracken M, Denisuik A, Golding G, Karlowsky JA, Hoban DJ, Zhanel GG. CANWARD 2013: Antimicrobial resistance in pathogens isolated from Canadian hospital clinics, emergency rooms, medical/surgical wards and intensive care units

Bekal S, Côté G, Nadeau M, Lefebvre B, Bharat A, Mandes R, Finley R, Tremblay C, Mulvey MR. Emergence of multidrug-resistant Salmonella Dublin from human and animal sources in Québec

Bekal S, Doualla-Bell F, Gaulin C, Gravel G, Tremblay C. Shiga-toxin producing Escherichia coli (STEC) infections in the province of Québec: Results of 13 years of surveillance program

Berenger B, Chui L, Borkent A, Lee M-C. Urinary tract infection caused by an unusual pathogen identified using cystine-lactose-electrolyte deficient media and matrix-assisted laser desorption ionization-time of flight mass spectrometry (Clinical Vignette Poster)

Bernard K, Pacheco Al, Burdz T, Wiebe D. Antimicrobial susceptibility testing (AST) by broth microdilution (BMD) using CLSI guidelines for Corynebacterium isolates referred to the National Microbiology Laboratory

Brar S, Doucette K. Descriptive analysis of HBV and HCV positive patients referred from a refugee clinic

Brooks A, Irfan N, Mithoowani S, Lee D, Carducci A, Celetti S, Cheng A, Mertz D. Risk factors for treatment of asymptomatic bacteriuria: Does an educational intervention reduce unnecessary treatment?

Broukhanski G, Lee C. Evaluation of a Colorex C difficile from CHROMagar for isolation of Clostridum difficile from stool specimens for characterisation and strain typing by molecular methods

Burstein B, Dubrovsky S, Quach C. Emergency department and inpatient management of febrile infants under six weeks of age: Perceived utility of respiratory virus testing

Campigotto A, Soares D, Mubareka S, Vearncombe M, Simor AE. Evaluation of selective media for the detection of ciprofloxacin-resistant Enterobacteriaceae (CR-E) from rectal specimens
Campigotto A, Wong H, Simor AE, McGeer A, Gubbay J, Green K, Hassan K, Mazzulli T, Mubareka S. Staphylococcus aureus and Streptococcus pneumoniae nasal colonization rates among patients with laboratory confirmed influenza virus infection

Carducci A, Brooks A, Sung M, Haider S, Mertz D, Irfan N. A clinical overview of tigecycline use at a tertiary care teaching organization over 5 years

Chahil N, Chu K, Mak A, Cook D, McNabb A, Krajden M. Dual enzyme immunoassay (EIA) screening for confirmation of HCV infection

Chambers C, Skowronski DM, Sabaiduc S, Purych D, Janjua Nz, De Serres G, Petric M, Krajden M, Kobasa D, Li Y. Seroprotection against emerging and re-emerging influenza viruses: Results of an agebased serosurvey, British Columbia, 2013

Chang Y, Ng C, Brodkin E, Mac B, Purych D, Boyd DA, Fakharuddin K, Mulvey MR, Hoang L. Application of multiple molecular methods for subtyping carbapenem-resistant Klebsiella pneumoniae and Enterobacter cloacae isolates from multiple hospitals

Charles M, Berenger B, Turnbull L-A, Rennie R, Fuller J. In vitro betalactam susceptibility testing of Streptococcus pneumoniae using Liofilchem gradient diffusion compared to CLSI broth microdilution

Charles M, Berenger B, Turnbull L-A, Rennie R, Fuller J. In vitro betalactam susceptibility testing of Streptococcus pneumoniae by commercial methods compared to CLSI broth microdilution

Chernesky M, Jang D, Flandin JF, Gilchrist J, Smieja M, Ratnam S. Comparison of continuous random access testing for $\mathrm{C}$ trachomatis on a Panther instrument to batch testing on a cobas 4800 System

Chong P, Unger M, Boyd DA, Westmacott G, Mulvey MR. Carbapenemase detection in clinically relevant Enterobacteriaceae and Pseudomonas aeruginosa by MALDI-TOF MS

Chou F, Croxen MA, Jassem AN, Pintar K, Pollari F, Paccagnella A, Isaac-Renton J, Hoang L, Prystajecky N. Pooled nucleic acid amplification test for screening of stool specimens for Shiga toxinproducing Escherichia coli

Chu K, Cook D, Mak A, Chahil N, Steinberg M, Gilbert M, Krajden M. Pooled nucleic acid testing increases the diagnostic yield of acute HIV infection compared to 3 and 4 generation HIV EIA

Chui L, Ferrato C, Louie M. Molecular serotyping for Salmonella

Chui L, Kassam R, Poon A. Heat-resistant Shiga toxin-producing Escherichia coli (STEC) - a new emerging pathogen?

Chui L, Li V, Fach P, Delannoy S, Malejczyk K, Poon A, King R, Lee M-C. Molecular profiling of human and cattle Shiga toxin-producing Escherichia coli strains in Alberta, Canada

Congly L. Comparison of Chicago Sky Blue (CB) and Calcofluor White $(\mathrm{CW})$ staining methods for the diagnosis of dermatomycosis $(\mathrm{DE})$ and onychomycosis $(\mathrm{ON})$

Conly J, Punja N, Kimberly H, Simmonds K, Bernard K, Carson J, Macdonald J, Friesen B. A highly unusual late autumn Legionella pneumophila serogroup 1 Knoxville sequence type 222 outbreak in an inner city neighborhood in Calgary, Canada

Daku D, DePaulo R, Thiry D, Mcdonald RR, Horsman GB, Levett PN. Detection of non-O157 Escherichia coli in Saskatchewan using chromogenic culture medium and PCR screening

Daley P, Penney C, Janes F, Midodzi W. Comparative performance of ESwab and M40 in extreme transport conditions 
Demczuk W, Lynch T, Martin I, Allen V, Hoang L, Lefebvre B, Lovgren M, Horsman G, Wong T, Archibald C, van Domselaar G, Graham M, Mulvey MR. Whole-genome sequencing of Neisseria gonorrhoeae isolates with reduced cephalosporin susceptibilities collected in Canada between 2001 and 2012

Demczuk W, Martin I, Sawatzky P, Liu G, Allen V, Hoang L, Lefebvre B, Lovgren M, Haldane D, van Caeseele P, Horsman GB, Ratnam S, Garceau R, Wong T, Archibald C, Mulvey MR. Antimicrobial susceptibilities and multi-antigen sequence types (Ng-Mast) of Neisseria gonorrhoeae isolated in Canada, 2008-2012

Denisuik AJ, Lagacé-Wiens P, Simner PJ, Mulvey MR, Baxter M, Adam HJ, Hoban DJ, Zhanel GG. Molecular epidemiology and virulence characteristics of extended-spectrum $\beta$-lactamase-producing Escherichia coli (EC) isolated in Canadian hospitals from 2007 to 2012

Deodhar S, Khatib S, Williamson M. Carriage of ciprofloxacin-resistant enteric organisms in patients undergoing transrectal ultrasound-guided biopsies of the prostate (TRUSBP): What we found and how we found it Dingle TC, Abbott AN, Fang FC. Clinical utility of reflexive throat culture on negative rapid antigen tests for the diagnosis of group A streptococcal pharyngitis in adults

Dixit D, Tang J, Grolla A, Taylor G. Straight from the cow's mouth (Clinical Vignette Poster)

Doll MK, Gagneur A, Charest H, Gonzales M, Buckeridge DL, Quach C. Effectiveness of rotavirus vaccination against severe rotavirus infection among children aged $<3$ years in Québec

Doll MK, Gonzales M, Charest H, Gagneur A, Buckeridge DL, Quach C. A prospective comparison of rotavirus and norovirus severe gastroenteritis following the implementation of a publicly funded rotavirus vaccine program in Québec

Dragan T, Sligl W, Smith S. Nosocomial Gram-negative bacteremia in a general systems intensive care unit: Epidemiology, antimicrobial susceptibility patterns, treatment and outcomes

Duplisea K, Nelson S, Morris A, Bunce P. Use of spot audits to measure appropriateness of antimicrobial therapy on general internal medicine as part of an antimicrobial stewardship program

Duplisea K, Nelson S, Olegario S, Morris A, Bunce P. A point prevalence study to measure appropriateness of antimicrobial prescribing on general internal medicine patients as part of an antimicrobial stewardship program

Efthimiadis A, Yamamura D, Darlington L, Nair P. Effect of minimizing salivary contamination by selective processing of sputum plugs on sputum microbiology

Eisler D, McNabb A, Tang P. Multiplex real-time PCR detection of herpes simplex viruses 1 and 2, varicella zoster virus and human beta-globin

Ellis C, Ciccotelli W. Comparison of BD MAX MRSA assay using a combined nasal/perianal Eswab to nasal and perianal swabs cultured on Chrom agar and broth enrichment media

Ellis C, Karnauchow T. Utilization of Bordetella pertussis and

$B$ parapertussis PCR testing in a regional children's hospital

Fearon M, Scalia V, O'brien S, Bigham M, Andonov A, Weger S, Bernier F, Dubuc S, Delage G, Germain M. Babesia and hepatitis E seroprevalence in Canadian blood donors

Fuller J, Shokoples S, Theoret Y, Robitialle R, Zeidler J, Colantonio D, Kulasingam V, Holmes D, Romney M, Pelletier R. Inter-laboratory comparability study of voriconazole therapeutic drug monitoring

Fuller J, Shokoples S, Turnbull L-A, Rennie R, Adam HJ, Baxter M, Hoban DJ, Zhanel GG. Antifungal susceptibility of invasive Candida isolates from Canadian hospitals: Results of the CANWARD 2013 study

Fuller J, Shokoples S, Turnbull L-A, Rennie R, Adam H, Baxter M, Hoban DJ, Zhanel GG. Antifungal susceptibility of respiratory Aspergillus isolates from Canadian hospitals: Results of the CANWARD 2013 Study

Gandhi B, Mazzulli T. A simple spectrophotometric method to measure flocked swab absorption as an alternative to complex research methods

Gao Y, Janes F, Kidney K, Ryan J, Daley P. Blinded comparative performance and efficiency of urine chromogenic agars
Garber G, Adomako K, Lam F, Robertson J, Prematunge C, Egan C. Developing a culture of evaluative research for infection prevention and control practice

Garber G, Adomako K, Prematunge C, Lam F, Didiodato G, Robertson J, Egan C. Changing trends in vancomycin-resistant enterococci (VRE) bacteremia: The power and pitfalls of using publicly reported infection rates Gauchier-Pitts K, Rennie R, Turnbull L-A, Oosterhoff C. Urine collection systems that are designed to preserve urinary pathogens during transport: Effect of system and transport time on bacterial survival

Ghosh A, Jiao L, Al-Mutawa F, O’Neill C, Mertz D. Value of an active surveillance policy to document clearance of methicillin-resistant Staphylococcus aureus and vancomycin-resistant Enterococcus amongst in-patients with prolonged admissions

Gnarpe J. The Brainspan learning game: Whats in it for instructors? Golden AR, Fultz B, Rosenthal M, Nichol KA, Adam HJ, Baxter M, Hoban DJ, Zhanel GG. Characterization of penicillin-resistant (PRSP) and multi-drug resistant (MDR) Streptococcus pneumoniae (SPN) in Canadian hospitals, 2007-2012

Haratian K, Fallah P. Comparison between intrathecal antibody production against neurotropic viruses in pediatric and adult onset multiple sclerosis

Haratian K, Fallah P, Meybodi AM. Type distribution of human papillomaviruses in non-familial breast cancer patients in Iran

Haratian K, Meybodi AM. Rapid detection of rotavirus in fecal specimens by PCR during acute gastroenteritis among children younger than 6 years of age

Hasan M, Young V, Al-Rawahi G, Thomas E, Tan R, Tilley P. A novel real-time PCR assay panel for the detection of common respiratory pathogens in a convenient, strip-tube array format

Hassan K, Volling C, Mazzulli T, McGeer A. Hospitalization due to respiratory syncytial virus (RSV) infection in immunosuppressed adults: A retrospective cohort study

Hatchette TF, Johnston L, Mask A, Lalany A, Haldane D, Drebot M, Baikie M, Cole T, Gould R, Lindsay R. Lyme disease in Nova Scotia: How many humans have been infected?

Hill C, Blondel-Hill E, Hadwell V, Jewsbury H, Wang B. Validation of susceptibility testing results from organisms isolated directly from Colorex Orientation ${ }^{\circledR}$ agar

Hill C, Johnson A, Blondel-Hill E, Hadwell V. Prevalence of extendedspectrum beta-lactamase, AmpC cephalosporinase, and carbapenemase producing Enterobacteriaceae over a four-year period in stool samples submitted to laboratories in the Okanagan region of British Columbia, Canada Hill C, Wang B, Johnson A. Evaluation of yeast MIC Strips (Liofilchem, Italy) for antifungal susceptibility testing

Himsworth C, Zabek E, Desruisseau A, Parmley J, Reid-Smith R, Jardine C, Tang P, Patrick D. Prevalence and characteristics of Escherichia coli and Salmonella spp. in the feces of wild urban Norway and black rats (Rattus norvegicus and Rattus rattus): Implications for public health

Hoang L, Kelly J, Severini A, Lester R. A new rise in an old disease: LGV in British Columbia 2004-2013

Hon B, Azana R, Hoang L. Validation of Hologic Gen-Probe APTIMA Combo 2 assay for Chlamydia trachomatis in eye specimens

Jassem AN, Prystajecky N, Marra F, Kibsey P, Tan K, Umlandt P, Janz L, Champagne S, BCAMM Members, Gamage B, Henry B, Hoang L. Molecular epidemiology of Clostridium difficile in a British Columbia community: Shift in pulsed-field gel electrophoresis profiles between 2008 and 2013

Jayaratne P, Dalle Vedove L, Yamamura D. Molecular detection of Pneumocystis jirovecii by real-time PCR

Johnstone J, Parsons R, Botelho F, Millar J, McNeil S, Fulop T, McElhaney J, Andrew M, Walter S, Devereaux PJ, Brinkman R, Malekesmaeili M, Mahony J, Bramson J, Loeb M. Immune biomarkers predictive of respiratory viral infection in elderly nursing home residents

Jones P, Guirguis M, Sobey A, Saxinger L. Reduction of Clostridum difficile infection (CDI) rates through stewardship: Difficulty engaging prescribers, with implications for stewardship project design 
Kadkhoda K, Smart G. Evaluation of PAB Lyme EIA for the diagnosis of Borrelia burgdorferi infection

Khan S, Kitai I. The case of the non-responding osteomyelitis (Clinical Vignette Poster)

Khateb A, Conly J, Wu K, Mcclure J, Armstrong G, Zhang K. Replacing the Staphylococcal Protein A (spa) gene alters its biological characteristics, behavior and virulence in a high-virulence community-associated methicillin-resistant Staphylococcus aureus (CA-MRSA) strain USA300

Kong L, Dendukuri N, Schiller I, Bourgault A-M, Brassard P, Poirier L, Lamothe F, Béliveau C, Michaud S, Turgeon N, Toye B, Frost E, Gilca R, Dascal A, Loo V. Predictors of asymptomatic Clostridium difficile colonization on hospital admission

Kornherr P, Guindon K, Nguyen L, Valupadas S. Evaluation of a novel enterococcosel enrichment broth in combination with a chromogenic VRE plate within a region of high VRE prevalence

Lang A, Al-Siyabi T, Roberts C, Mazzulli T, Hatchette TF, Leblanc J. Does the BD Viper HSV-Qx assay require a grey zone?

Lang A, El-Sherif M, Hatchette TF, McNeil S, Leblanc J. Comparison of two molecular typing methods for Streptococcus pneumoniae

Lee MK, Man S, Fernando K, Lo T, Wong Q, Henry B, Morshed M. Update on the molecular characteristics of West Nile virus in British Columbia

Lee T, Adie K, McNabb A, Hoang L, Tang P. Development of a real-time PCR assay for the differentiation of Streptococcus pneumoniae and Streptococcus pseudopneumoniae

Lefebvre M-A, Daniel SJ, Quach C. Chronic Otitis media due to nontuberculous Mycobacteria: A case of successful treatment with topical boric acid (Clinical Vignette Poster)

Lester R, Hottes T, Chang Y, Hoang L. Reversal of gonorrhea antibiotic resistance trends in British Columbia: Can we save the oral option?

Leto D, Jiao L. A case of Leclercia adecarboxylata bacteremia in a neutropenic patient

Levett PN, Ash T, Gibbs D, Wang A, Thierjung N. Study of BIOMIC V3 automated versus manual reading of MicroScan ESBL Plus panel results

Lloyd T, Carson J, Chan W, Pillai D. RIDA®GENE Parasitic Stool Panel and xTAG ${ }^{\circledR}$ Gastrointestinal Pathogen Panel for the detection of common intestinal parasites

Lowe C, Merrick L, Ritchie G, Sherlock C. Evaluation of the COBAS® AmpliPrep/TaqMan ${ }^{\circledR}$ CMV test for CMV quantitative viral load testing

Lowther N, Eisler D, McNabb A, Tang P. Detecting Mycobacterium avium complex in respiratory specimens by a duplex qPCR using the ABI 7900 Fast Real-Time PCR System

Lungrin D, James D, Leto D, Almohri H. The prevalence of common intestinal parasitic pathogens from community patients in Ontario 2008-2012

Luo I, Montoya V, Olmstead A, Lamoury F, Applegate T, Grebely J, Krajden M. Phylogenetic analysis of distinct hepatitis $\mathrm{C}$ virus genomic regions for identification of transmission clusters in British Columbia

Lyle N, Fjell C, Hancock D, Boyd J, Hancock R. Elevated S100A12 gene expression at the time of initial presentation is associated with increased severity of illness during sepsis

Mahmoud MA, da Silveira Cavalcante L, Holovati JL, Keelan MM. Antibacterial activity of stearylamine-containing liposomes against Helicobacter pylori

Maier A, Krolik J, Belanger P, Majury A. A five-year assessment of private well owner submission behaviours in Southeastern Ontario

Martin L, Tova-Harris M, Tayeb S, Brooks A, Main C, Mertz D. Management and outcomes in patients with Staphylococcus aureus bacteremia after implementation of an automated infectious diseases consult: A before/after study

Materniak S, Steves C, Kunimoto D, Mackenzie H, Webster D. Impact of a borderline zone on the concordance of tuberculin skin test and interferon gamma release assay results among a low-risk cohort in Maritime Canada

Mazzulli T, Khine AA, Stone C, Shah B, Talebpour S, Maaskant R, Alavie T. Use of electrical treatment for the recovery of microbial ribosomal RNA followed by RT-PCR for the detection and identification of bacteria and fungi in blood samples

Mazzulli T, Moussa G, Rottengatter K, Hess M. Evaluation of molecular assays for the detection of influenza viruses and RSV in respiratory specimens

McGeer A, Green K, Rudnick W, Shigayeva A, Pong-Porter S, Plevneshi A, Toronto Invasive Bacterial Diseases Network. Impact of conjugant pneumococcal vaccine programs on rates of invasive pneumococcal disease (IPD), 2001-2013

Mendoza L, Hiebert J, Peterson A, Beirnes J, Podhorodecki L, Schulz H, Severini A. Measles, mumps and rubella virus genotypes identified in Canada in 2012 and 2013

Mitchell K, Vayalumkal J. Sickness presenteeism among general paediatrics resident physicians in Canada

Mulvey MR, Weger S, Finley R, Langner S, Allen V, German G, Bekal S, El Bailey S, Haldane D, Hoang L, Horsman GB, Louie M, Robberts L, Wylie J, Parmley J, Léger D, Avery B, Irwin R. The re-emergence of multidrug-resistant Salmonella enterica serotype Newport in Canada: Is there an animal-food link?

Musa J, Bramberger D, Nigh S, Almohri H. Comparison of sabouraud dextrose agar with cyclohexamide, chloramphenicol and gentamicin media prepared by three different suppliers

Perrault L, Zhanel GG, Laroche C, Lelorier J, Mitchell D, Dahan S. Cost of fosfomycin compares favourably to reimbursed agents as empirical treatment of uncomplicated urinary tract infections

Peterson S, Martin I, Demczuk W, Hoang L, Wylie J, Allen V, Lefebvre B, Lovgren M, Horsman GB, Haldane D, Wong T, Archibald C, Mulvey MR. A preliminary molecular-based assay for the detection of antimicrobial resistant Neisseria gonorrhoeae

Poutanen SM, Rennie R, Roscoe D, Toye B, Lee C, Loo V, Hoban D, Grimard D, Jutras P, Blondeau J, Pitout J, Gilchrist SE, Pouliot J-F. Increase in prevalence of extended-spectrum $\beta$-lactamase (ESBL) producing Gram-negative bacilli (GNB) isolated from patients with intra-abdominal infections in Canada from 2008-2012

Qiu Y, Adachi D, Pang XL. Comparison of nucleic acid extraction from stool samples among four autoextractors and their performance for detection of gastroenteritis viruses using real-time RT-PCR

Rajapakse N, Carson J, Pillai D, Read R. An unusual case of Gram-negative meningitis

Rajapakse N, Vayalumkal J, Pearce C, Rees G, Kamhuka L, Peirano G, Pidhorney C, Ledgerwood D, Alfieri N, Hope K, Gregson D, Pitout J, Louie T, Conly J. To sCREen or not to sCREen for carbapenem-resistant

Enterobacteriaceae in recipients of out-of-country medical care: A cost analysis

Remington L, Fuller J, Mauricio W, Chiu I. Chronic necrotizing aspergillosis in a diabetic patient using marijuana

Rooney B-L, Binkhamis K, Pettipas J, Grudeski E, Pang XL, Booth T, Hatchette TF, Leblanc J. Detection of circulating norovirus genotypes: Hitting a moving target

Sant N, Desjardins M, Chirip V, Ettinger R, Gorn I, Roth V. Pseudooutbreak of Mycobacterium fortuitum due to contaminated ice machines

Saxinger L, Grant J, Keen P, Patrick D. Surveillance of antimicrobial resistance (AMR) and antimicrobial utilization (AU) in Canada: Final results of a comprehensive review and ten recommendations to achieve optimal Canadian surveillance programs

Saxinger L, Smith S, Taylor G. Shifts in epidemiology of blood stream infection (BSI) on an inpatient hematology ward: Piperacillin tazobactam resistance, and implications for empiric febrile neutropenic treatment

Schwartz IS, Dlamini S, Govender N, Corcoran C, Prozesky HW, Mendelson M, Taljaard J, Colebunders R, Kenyon C. Emmonsiosis in South Africa - clinical and laboratory features of 27 cases

Schwartz IS, Keynan Y, Gilmour MW, Dufault B, Lagacé-Wiens P. Changing trends in $\beta$-hemolytic streptococcal bacteremia in Manitoba, Canada: 2007-2012

Sekirov I, Ng C, Azana R, Mack B, Kibsey P, Stefanovic A, Champagne S, Blondel-Hill E, Hoang L. Carbapenemase producing organisms in BC, 2008-2013 
Serhir B, Dagenais C, Ogee-Nwankwo A, Lamirande R, Hatchette TF, Crowcroft N, Doualla-Bell F, Tremblay C. Validation of a plaque reduction neutralization test for rubella: Performance comparison with virus-specific IgG EIAs

Serhir B, Hamel D, Routy JP, Beaulac S-N, Legault M, Fauvel M, Doualla-Bell F, Tremblay C. Performance of two avidity assays, Bio-Rad Avidity and Sedia Lag Avidity, to estimate recent HIV infection in Québec

Severini A, Zubach V, Roy F. Genotyping of lymphogranuloma venereum Chlamydia serovars at the National Microbiology Laboratory

Sharma M, Christianson S, Karlowsky J, Kein D, Smart N, Wolfe J. Evaluation of the TBcID assay for the detection of Mycobacterium tuberculosis complex organisms directly from liquid culture

Sheth P, Tadros M, Small W, Hussain Z. Evaluation of the B-LACTA Test for the rapid detection of extended spectrum beta lactamases in Enterobacteriaceae from perianal swabs

Shroff A, Haider S. Seeing red: A curious skin manifestation Shroff A, Murdoch J, Brooks A, Irfan N, O'Shea T. Post-splenectomy immunization at tertiary care facilities in Hamilton, Ontario

Simmonds K, Fathima S, Chui L, Lovgren M, Shook P, Shuel M, Tyrrell G, Tsang R, Drews S, Hosein S, Drews S. Epidemiology of Bordetella pertussis genotypes in Alberta: January 2012 - August 2012

Simor AE, Williams V, McGeer A, Han G, Hirji Z, Larios O, Weiss K, Kiss A. Is the prevalence of methicillin-resistant Staphylococcus aureus (MRSA), vancomycin-resistant enterococcus (VRE), extended-spectrum $\beta$-lactamase-producing Enterobacteriaceae (ESBL), carbapenem-resistant Enterobacteriaceae (CRE) and Clostridium difficile infection (CDI) changing in Canadian hospitals? A comparison of survey results in 2010 and 2012

Somayaji R, Berthiaume L, Fonseca K, Conly J. 'GRAINS’ Of Wrath (Clinical Vignette Poster)

Soualhine H, Spinato J, Bélanger-Trudelle E, Côté L, Tremblay C. Molecular characterization of drug resistant Mycobacterium tuberculosis in the province of Québec

Tan K, Walker B, Hoang L, Kibsey P. Two-step identification of Shigatoxigenic Escherichia coli (STEC) with chromogenic media (CGM) and enzyme immunoassay (EIA) from human stool specimens

Tong Y, Lee B, Pang XL. Rapid genotyping of human rotavirus using a SYBR Green real-time RT-PCR with melting curve analysis

Tong YT, Pang XL, Preiksaitis JK. Determination of the biological form of human cytomegalovirus DNA in the plasma of solid organ transplant recipients

Wan M, Luong C, So P, Wong E, Wong W, Gabriel S, Crump M, Doyle P. C the DIFFerence: Strategies for improving early appropriate isolation in suspected $\mathrm{C}$ difficile cases

Ward L, McCombie R, Harrison L, Leavitt J, Conly J, Louie T. Buyer beware: Investigation of an automated washer unit for cleaning and sanitizing commodes on an acute care blood and marrow transplanthematology-oncology ward and implications for microbial transmission

Wen A, Broukhanski G. Clostridium difficile: A study in the search for features associated with the ability to cause outbreaks

Whellams D, Main C, Mertz D, Singhal N. Practices surrounding outpatient antibiotic therapy for intravenous drug users: A survey

Willey BM, Oleung O, Tsang A, Kim S, Manji I, Ramoutar E, Tharmaradinam S, Lo P, Poutanen SM. Use of chromogen specificity in urine agars to reduce MALDI-TOF workload associated with identification (ID) of Escherichia coli

Willey BM, Ramoutar E, Lo P, Poutanen SM. VITEK MS PLUS (VMS) identification (ID) performance when challenged with mixed bacteria (MB) or mixed yeast (MY) cultures

Willey BM, Trimi S, Boyd Da, Tsang A, Manji I, Oleung O, Kim S, Lo P, Mulvey MR, Poutanen SM. Colorimetric detection of 3rd generation cephalosporin resistance (3GCR) in Enterobacteriaceae (ENT): A retrospective evaluation of the Rapid Bio-Rad BLACTA Test (BLT)

Willey BM, Trimi X, Lo P, Poutanen SM. Pilot prospective evaluation of the BLACTA Test (BLT) for predicting 3 generation cephalosporin resistance (3GCR) in short-incubation blood culture isolates (SIBCI) of Escherichia coli (EC), Klebsiella pneumoniae (KP), Klebsiella oxytoca (KO) and Proteus mirabilis (PM)

Willey BM, Vermeiren C, Ricci G, Watt C, Lo P, Simor A, Poutanen SM. Use of Wellcolex Colour Shigella (WCS) latex agglutination to detect Shigella among non-lactose fermentors (NLF) identified (ID) by MALDI-TOF as Escherichia coli

Williams V, Simor AE, McGeer A, Han G, Hirji Z, Kiss A, Larios O, Weiss K. A survey of infection prevention and control policies for the management of methicillin-resistant Staphylococcus aureus (MRSA), vancomycin-resistant enterococcus (VRE), and Clostridium difficile infection (CDI) in Canadian hospitals

Wong A, Boyd DA, Golding G, Graham M, Frenette C, Holmes L, Katz K, Kibsey P, McGeer A, Miller M, Moore D, Simor AE, Suh K, Taylor G, Zhanel GG, Gravel D, Mulvey MR, Canadian Nosocomial Infection Surveillance Program (CNISP). Identification and

characterization of a Clostridium difficile isolate with reduced susceptibility to vancomycin

Wong J, Auk B, Wong B, Prystajecky N, Moreau D, Hoyano D, Kibsey P, Isaac-Renton J. Foodborne botulism: Urgent collaboration and consultation required

Wood M, Forgie S. Using photography-based social media in infectious diseases education: \#A picture is worth a 1000 microbes \#Instagram positive in medical education

Xiong J, Kong T, Hancock D, Chapman W. Validation of BD BACTEC $^{\text {тм }}$ PLUS plastic aerobic/F resin medium using recommended reference ATCC strains seeded blood culture and BD BACTEC ${ }^{\mathrm{TM}} \mathrm{FX}$, 9240 and 9120 instruments

Yang Y, So M, Hussain S, Bell C, Morris A. Evaluation of antimicrobial prescribing in hospitalized solid organ transplant recipients through serial real-time point prevalence audits

Yu Y, McCaffrey W, McConnell M, Irfan N, Yamamura D. Organism identification on early subculture colonies by VitekMS matrix-assisted laser desorption ionization-time of flight (VITEKMS) and its impact on antibiotic stewardship

Zelyas N, Gee S, Rennie R, Nilsson B, Bennett T. Infections caused by Actinomyces neuii: A case series and literature review of an unusual bacterium Zheng BJ, Chan KW, Lau SKP, Woo PCY, Chan KH, Jin DY, Yuen KY. Combination use of antiviral and anti-inflammatory agents against lethal infection of avian influenza virus H5N1 in animal model

Zhou L, Hoang L, Petric M. Comparison of viral transport medium and amies transport medium with charcoal for the detection of Bordetella pertussis by PCR 


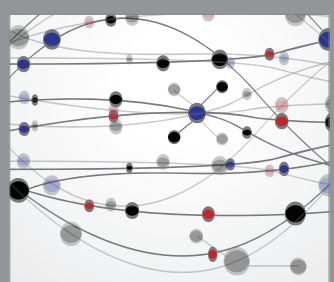

The Scientific World Journal
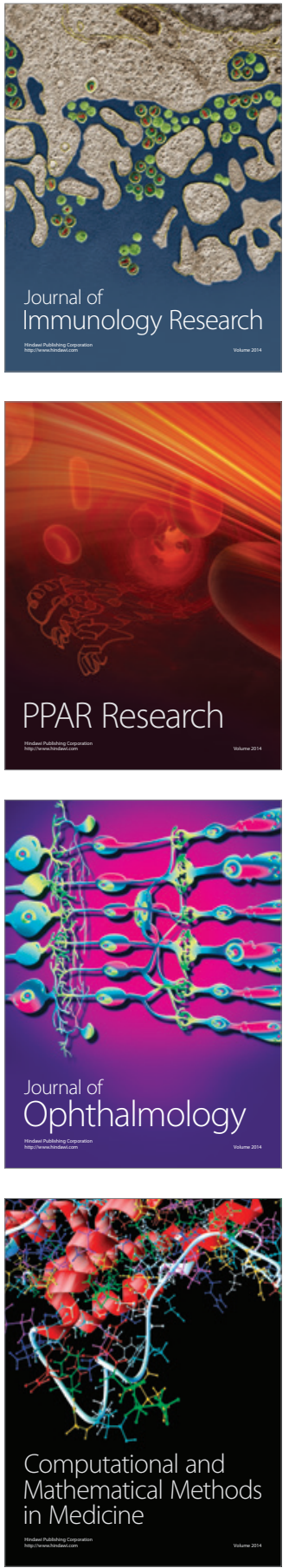

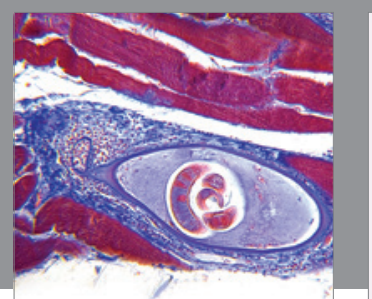

Gastroenterology Research and Practice

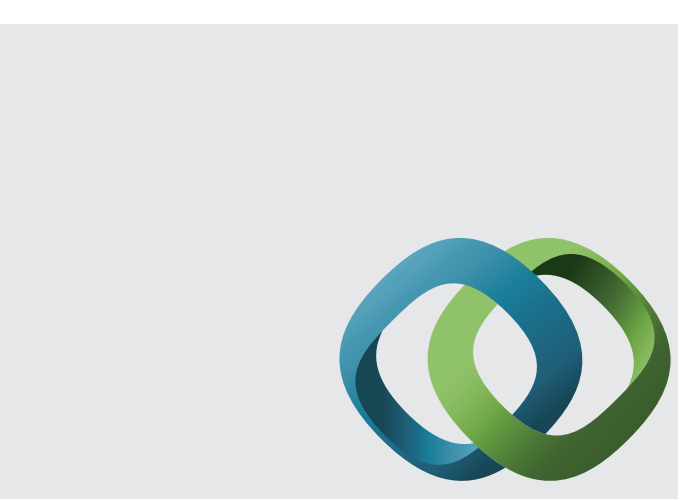

\section{Hindawi}

Submit your manuscripts at

http://www.hindawi.com
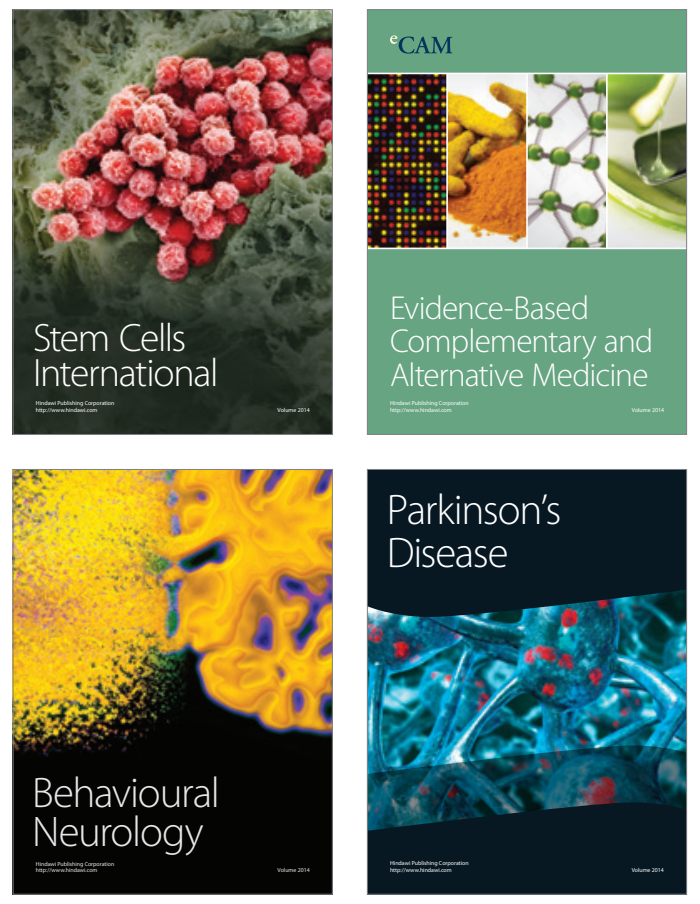
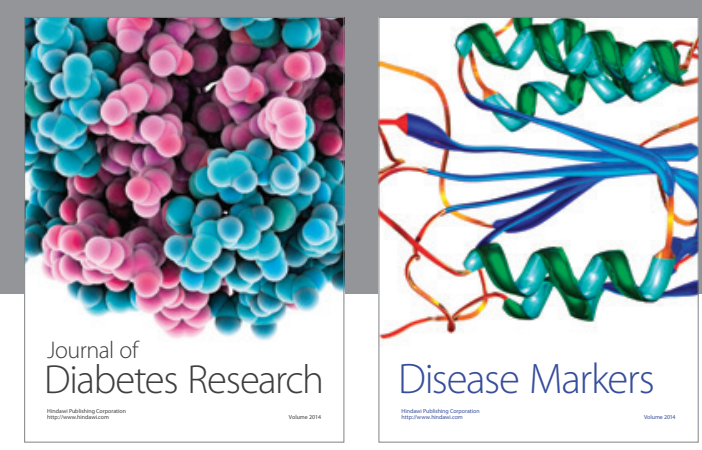

Disease Markers
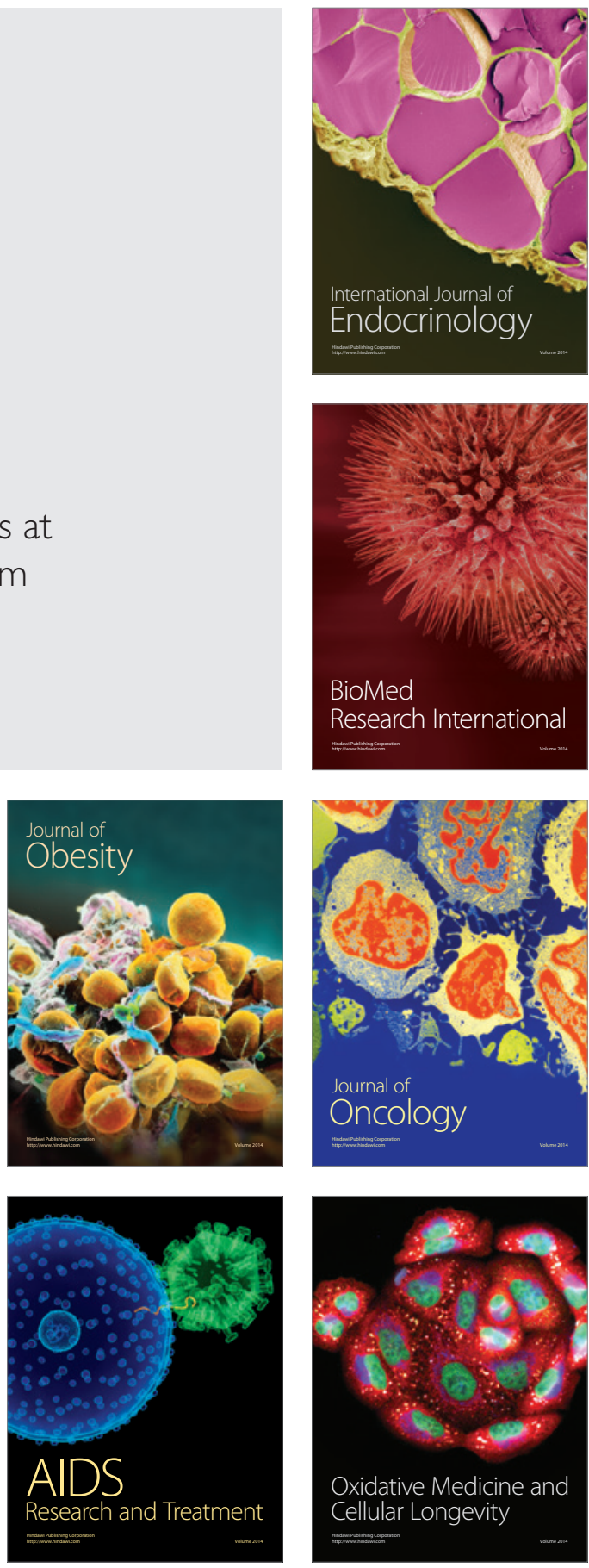